\title{
The effect of boron fertilization on spring cereals
}

\author{
HILKKA TÄHTINEN \\ Agricultural Research Centre, Institute of Agricultural Chemistry and Physics, \\ 01300 Vantaa 30
}

\begin{abstract}
The research material was collected in the period from 1947-69, and was based on grain yields obtained in field experiments carried out with spring cereals in various parts of Finland. Fertilizers were used with and without boron. The boron, from 0.9 to $2.8 \mathrm{~B} \mathrm{~kg} / \mathrm{ha}$, was applied mainly as fertilizer borate and was mixed into the soil during seed bed preparation. The size of yield when boron was not applied did not depend significantly on the $\mathrm{pH}$, calcium, phosphorus or boron content of the soils. The difference in yield obtained with boron fertilization varied from -520 to $+580 \mathrm{~kg} / \mathrm{ha}$. Hot water-soluble boron in the soil, and the joint effect of this and acid ammonium acetate-extractable calcium gave the best correlation with the yield differences. It appears that it is possible to improve the test value of hot water-soluble boron by taking into account the type of soil and its calcium content.
\end{abstract}

Boron is one of the micronutrients that must be included in fertilizers used in many parts of Finland. The increasing use of fertilizers and the vigorous growth of plants induced by it exhaust the natural boron reserves in the soil. Attention has frequently been drawn to boron deficiency in the cultivation of plants requiring and abundant uptake of boron. In recent years, symptoms of boron deficiency have also become increasingly common in cereals. In Finland, a low content of hot water-soluble boron has been observed to occur most frequently on peat soils and on finesand soils of the central and eastern parts of the country (KURKI 1972).

The need for boron fertilization is fundamentally determined by the plant cultivated. Dicotyledons use considerably more boron than monocotyledons. Boron in the largest amounts is required by root crops of the genus Beta. Crucifers and legumes likewise utilize boron in abundance. The boron need of cereals is quite small, amounting to about a quarter of the requirements of the above-mentioned plants (BERGER 1949, LuCAS and KNEZEK 1972).

The first trials concerning boron fertilization were performed in Finland as early as 1928 , when boric acid was used to control heart rot in sugar beets growing on excessively limed fields (Krviniemi 1946). Boron field experiments were started in the 1930 s with sugar beet and swede and subsequently with cruciferous oil plants and big-leafed turnip (JAMALAINEN 1935 and 1949, TAInio 
1957, TÄhtinen 1970). Considerable yield increases resulting from boron were also obtained in red clover seed production (HäNNINEN 1966).

Since 1941, boron fertilization experiments have been performed with cereals in the experimental fields of the institute of Agricultural Chemistry and Physics. Boron has been shown to increase yield and its boron content as well as to reduce ergot contamination (TAINio 1961). Simojoki (1972) has found also that sowing time and earliness of barley varieties influence the appearence of boron deficiency.

In the following, variations of the effects of boron fertilization and the dependence of the effects on the chemical properties of these boron deficient soils are considered.

\section{Material and methods}

The material of the present study is drawn from boron fertilization experiments performed with cereals on the soils with a low content of hot watersoluble boron in various parts of Finland in the years 1947-69. The study involved yield data obtained with and without boron. There were 62 pairs of treatments. The plots received NPK basic fertilization. Before the fertilizers were applied, samples were taken from the topsoil. Soil analysis were made (VUORINEN and MÄKITIE 1955, KURKI et al. 1965) including boron determination (HATChER and Wilcox 1950) by extraction with boiling water (BERGER and TRUOG 1939). The amount of hot water-soluble boron in the soils varied from 0.1 to $0.4 \mathrm{~B} \mathrm{mg} / \mathrm{l}$ of soil. $68 \%$ of the experiments were performed with barley, $22 \%$ with oats and $10 \%$ with spring wheat.

The boron fertilizer used was mainly Fertilizer Borate 46. In some of the experiments, borax was used and in only a few, boric acid. The amount of

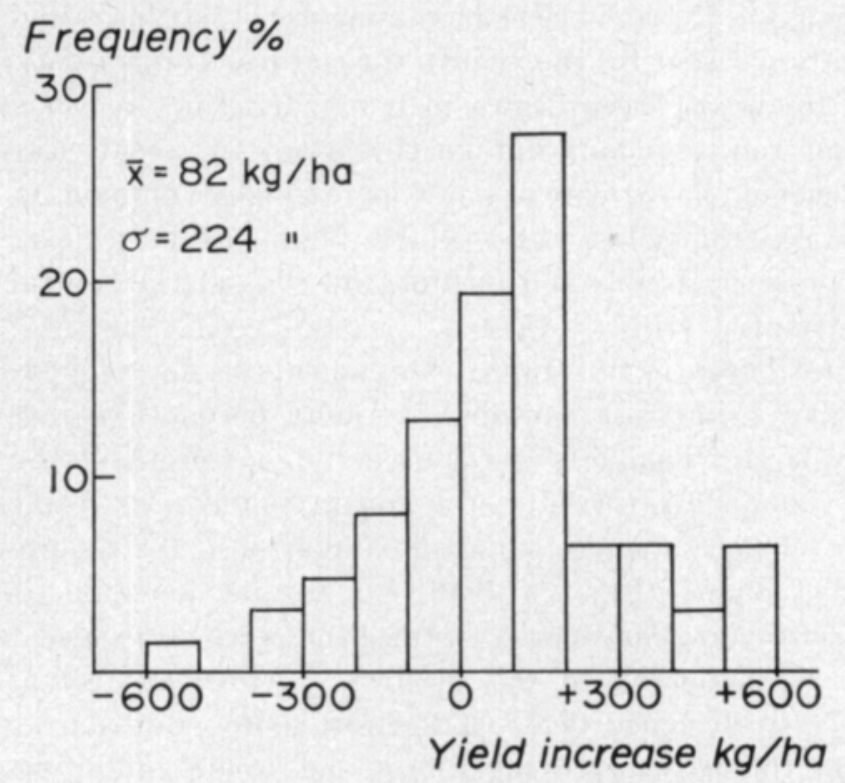

Figure 1. Frequency distribution of yield differences obtained with boron fertilizer. 
Table 1. Data on experiments with boron fertilization, $1947-69$ (average $\overline{\mathbf{x}}$, standard deviation $\sigma$ and range w)

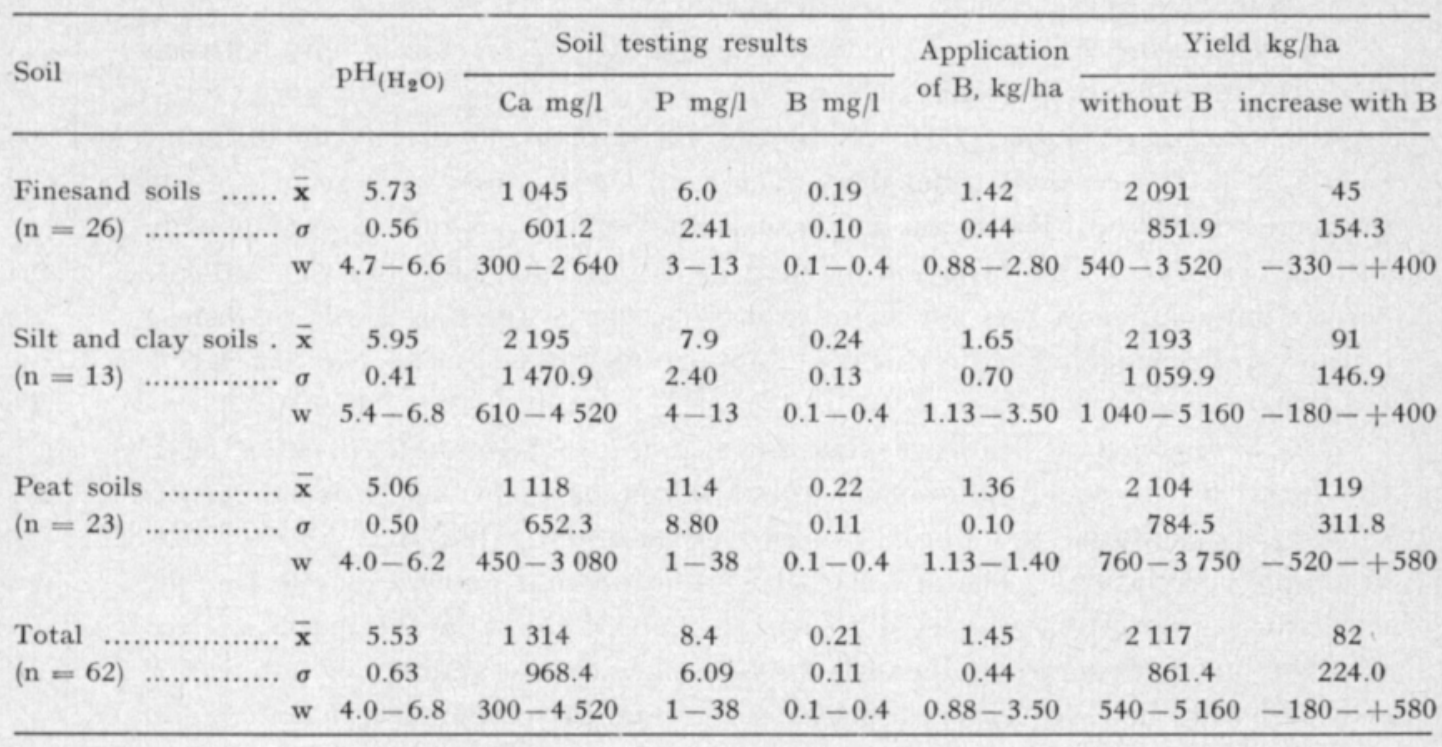

boron varied from 0.9 to $2.8 \mathrm{~kg} / \mathrm{ha} \mathrm{B}$, and in $91 \%$ of the cases the amount was 1.4 or less. The boron was mixed in the soil during seed bed preparation. The differences in grain yield obtained with boron fertilization were on average $+82 \mathrm{~kg} / \mathrm{ha}$, varying from -520 to $+580 \mathrm{~kg} / \mathrm{ha}$ (Fig. 1). Data summarising the research material are presented in Table 1.

In the statistical analysis of the material, regression analysis was used to study 1) the dependence of the yield obtained without boron upon the soil properties $\mathrm{pH}_{\mathrm{H}_{2} \mathrm{O}}$, acid ammoniumacetate extractable calcium and phosphorus and content of hot water-soluble boron, and 2) the dependence of the yield increases obtained with boron fertilization upon the amount of boron used and the abovementioned soil properties. Simple and multiple correlations were worked out and also partial and net regression coefficients were determined by stepwise regression analysis. The variables were used both linearly and non-linearly $\left(x^{2}\right.$ or $\left.\sqrt{x}\right)$. For the definitive equations the variables that proved significant in the soil groups were chosen.

\section{Results and discussion}

The research material was divided into three soil groups: peat soils, silt and clay soils, and finesand soils. The following statistically singificant differences were revealed between different soil groups:

- The peat soils were more acid than the others. The difference in comparison with the silt and clay soils was highly singificant $(\mathrm{P}<0.001)$.

- In the silt and clay soils, the calcium content was significantly $(\mathrm{P}<0.01)$ higher than in the other soils. 
- The difference in phosphorus contents between the silt and clay soils and the finesand soils was significant $(\mathrm{P}<0.05)$.

In the various soil groups, there was a significant correlation only between the $\mathrm{pH}$ and calcium content.

The variation in the grain yields obtained without boron on the different soils and on the total material did not depend significantly on any of the soil properties analysed. By means of the variables it was possible to explain only $11-22$ per cent of the variation in yield in the various soils, and the multiple correlation coefficient was not significant. The use of the non-linear treatment of the variables instead of the linear did not significantly improve the correlation coefficient.

The dependence of the yield increase obtained with boron fertilization upon the level of the yield obtained without boron or upon soil properties $(\mathrm{pH}$, calcium, phosphorus and boron contents) was investigated first on the basis of simple correlations. The effect of the boron did not depend on the amount used, for its variation was held to within a small range in the material. Nor was the yield increase significantly correlated with the amount of hot watersoluble boron, in these boron-deficient soils. The correlation coefficients were:

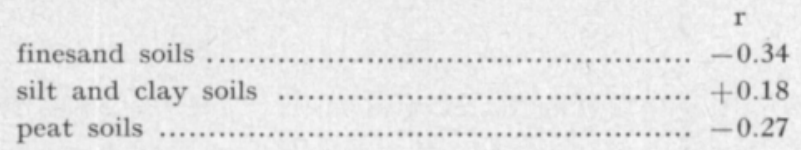

As in other boron fertilization experiments with cereals in this country, hot water-soluble boron has failed to give a satisfactory prognosis of boron deficiency in cereals (TÄнтіNen 1970, Siмојокі 1972). In the case of plants with a higher boron requirement, it has generally been possible to determine satisfactorily the boron requirement with water-soluble boron, although exceptions have occurred even in experiments with sugar beet (HAMENCE and ORAm 1964). The significance of threshold values of water-soluble boron for different plants is influenced, however, by many factors, such as soil texture (Rogers 1947, Wear and PAtterson 1962), the range of plant-available water (Dawson and Gustafson 1945, Lehr and Henkens 1959, Johansson and Nilsson 1973) and rate of fertilization (NeLyubova et al. 1971, Johansson and NiLsson 1973). In the present material, the effect of boron on the yield is more closely correlated with calcium content in soil than with its $\mathrm{pH}$. The correlation between yield increase and calcium content was statistically significant only in the case of finesand soils $\left(r=0.54^{* * *}\right)$. Multiple regression calculations indicate that the joint effect of the calcium and boron contents was significant in all the soil groups. The best yield increase prognosis were the boron value and its joint effect with calcium content of the soil as linear variables. In the case of boron-deficient soils, even slight variations in the boron content had a statistically significant effect on the magnitude of the yield difference obtained with boron fertilization (Table 2). The greatest variation in the critical boron content for different plants is explained by the soil texture as well as soil acidity (Rogers 1947, Fox 1968). In an experiment performed with maize in a greenhouse, Martens (1968) found the $\mathrm{pH}$ to ba 
Table 2. Response of grain yield to boron in relation to boron and calcium contents of soils. Results of the multiple regression analysis, $y=a+b_{2} x_{1}+b_{2} x_{1} x_{2}, y=$ response of grain yield $\mathrm{kg} / \mathrm{ha}, \mathrm{x}_{1}=$ hot water-soluble boron $\mathrm{B} \mathrm{mg} / \mathrm{l}, \mathrm{x}_{2}=$ acid ammoniumacetate extractable calcium Ca $\mathrm{mg} / \mathrm{l} . \mathrm{R}=$ multiple correlation coefficient.

\begin{tabular}{lrrll}
\hline & $\mathrm{a}$ & \multicolumn{1}{c}{$\mathrm{b}_{1}$} & \multicolumn{1}{c}{$\mathrm{b}_{2}$} & \multicolumn{1}{c}{$\mathrm{R}$} \\
\hline Finesand soils ............. & +106.568 & $-791.895^{*}$ & $+0.492^{*}$ & $0.499^{*}$ \\
Silt and clay soils ......... & -3.592 & $+984.493^{*}$ & $-0.241^{* *}$ & $0.747^{*}$ \\
Humus and peat soils .... & +369.848 & $-1920.025^{*}$ & $+0.647^{*}$ & 0.500 \\
\hline
\end{tabular}

$$
\begin{array}{rrrr}
\text { Significances: * } & 0.01 & <\mathrm{P}<0.05 \\
\text { *.*. } & 0.001 & <\mathrm{P}<0.01 \\
& & <\mathrm{P}<0.001
\end{array}
$$

even more indicative than water-soluble boron, although both together gave a better result. The calcium content of the soil was not determined in this study.

In the present investigation, the yield increase obtained with boron on peat soils was generally greatest on the soils with the lowest hot water-soluble boron content, especially, when the calcium content of the soil was low. On finesand soils, the joint effect was similar but weaker. On silt and clay soils, which contained significantly more calcium, the increase in the calcium content reduced the positive effect of the boron fertilization. The joint effect of the boron and calcium contents significantly deviated in silt and clay soils from the joint effect observed in finesand and peat soils. Owing to the higher calcium content of silt and clay soils, the effects of the soil groups and their calcium content could not be separated. Also the moisture content, which depends in part on the soil type, has a fundamental effect on the boron uptake of plants. Neither information on the moisture content of the soil nor reliable data on precipitation during the growing season is available, since there is no meteorological station near the experimental fields.

No fertilizing recommendations based on boron and calcium contents can be made exclusively on the basis of the present research material, mainly because of the insufficient data and the differences in calcium contents of the soil groups. The results indicate, however, that it is possible to improve the value of the soil analyses as a basis for boron fertilization recommendations.

\section{REFERENCES}

Berger, K. C. 1949. Boron in soils and crops. Adv. Agron. 1: $321-348$.

_- \& Truog, E. 1939. Boron determination in soils and plants. Ind. Eng. Chem., Anal. Ed. 11: 540-545.

Dawson, J. E. \& Gustafson, A. F. 1945. A study of techniques for predicting potassium and boron requirements for alfalfa. II. Influence of borax on deficiency symptoms and the boron content of the plant and soil. Soil Sci. Soc. Amer. Proc. 10:147-149.

Fox, R. H. 1968. The effect of calcium and $\mathrm{pH}$ on boron uptake from high concentrations of boron by cotton and alfalfa. Soil Sci. 106: 435-439. 
Hamence, J. H. \& Oram, P. A. 1964. Effects of soil and foliar applications of sodium borateto sugar beet. J. Sci. Food Agric. 15: 565-579.

Hatcher, J. D. \& Wilcox, L. V. 1950. Colorimetric determination of boron using carmine. Anal. Chem. 22: 567-569.

Hänninen, P. 1966. Boron fertilization and red clover seed production in central Finland. J. Scient. Agric. Soc. Finl. 107: 154-160.

Jamalainen, E. A. 1935. Tutkimuksia lantun ruskotaudista. Referat: Untersuchungen über die "Ruskotauti-Krankheit der Kohlrübe. Valt. Maatal.koetoim. Julk. 72:1-117.

- - 1949. Boorin puutteesta aiheutuvista kasvitaudeista ja boorin merkityksestä maamme kasvinviljelyssä. Summary: On boron deficiency diseases and on the role of boron in the Finnish plant cultivation. Valt. Maatal.koetoim. Julk. 130: 1-48.

Johansson, O. \& NiLsson, L. G. 1973. Borgödsling till höstoljeväxter. Lantbr.högsk. Rapp. Avd. Växtnäringslära 62:1-17.

Krviniemi, K. J. 1946. Havaintoja kalkin käytōstä, sen tarpeesta ja vaikutuksesta maassamme tämän vuosisadan aikana. [Observations on the use of lime, its requirements and effects in Finland during this century.] Manuscript in Finnish 73 p. [Available at Dept. of Agric. Chem. and Phys., Vantaa, Finland.]

KURKI, M. 1972. Suomen peltojen viljavuudesta. II. Referat: Uber die Fruchtbarkeit des. finnischen Ackerbodens auf Grund der in den Jahren 1955-1970 durchgeführten Bodenfruchtbarkeitsuntersuchungen.

- - Lakanen, E., Mäkitie, O., Sillanpää, M. \& Vuorinen, J. 1965. Viljavuusanalyysien. tulosten ilmoitustapa ja tulkinta. Summary: Interpretation of soil testing results. Ann. Agric. Fenn. 4:145-153.

LeHR, J. J. \& Henkens, C. H. 1959. Threshold values of boron contents in Dutch soils in relation to boron deficiency symptoms in beet (heartrot). Rep. Wld. Congr. Agric. Res., Rome, p. 1397-1407. (Ref. Smilde, K.Y. 1970)

LucAs, R. E. \& KNEZEK, B. D. 1972. Climatic and soil conditions promoting micronutrient deficiencies in plants. Micronutrients in Agriculture. p. 265-283. Wisconsin.

Martens, D. C. 1968. Plant availability of extractable boron, copper and zinc as related toselected soil properties. Soil. Sci. 106: 23-28.

Nelyubova, G. L., Mukha, N. A. \& Mazepova, K. V. 1971. Sensitivity of carrots to boron at various levels of nitrogen nutrition. Docl. TSKHA 169: 89-94. (Ref. Boron Agric. 100: 31.)

Rogers, H. T. 1947. Water-soluble boron in coarse-textured soils in relation to need of boron fertilization for legumes. J. Amer. Soc. Agron. 39: 914-927.

Sгмојокг, P. 1972. Tuloksia ohran boorilannoituskokeista. Ann. Agric. Fenn. 11: 333-341.

Smilde, K. W. 1970. Soil analysis as a basis for boron fertilization of sugar beets. Z. Pfl.ern. Bodenk. 125:130-143.

TAINIO, A. 1957. Boorilannoituksen merkityksestä syysrypsillä. Koetoim. ja Käyt. 14:9-10. - - 1961. Voidaanko hivenaineilla torjua torajyvää? Koetoim. ja Käyt. 18: 39.

TÄHTıNEN, H. 1970. Boorilannoituksen jälkivaikutus. Summary: Residual effect of boron fertilization. Ann. Agric. Fenn. 9: 331-335.

Vuorinen, J. \& Mäкıтı́, O. 1955. The method of soil testing in use in Finland. Selostus: Viljavuustutkimuksen analyysimenetelmästä. Agrogeol. Publ. 63:1-44.

Wear, J. I. \& Patterson, R. M. 1962. Effect of soil pH and texture on the availability of water-soluble boron in the soil. Soil Sci. Soc. Amer. Proc. 26: $344-346$. 


\title{
Boorilannoituksen vaikutus kevätviljoilla
}

\author{
HILKKA TÄHTINEN \\ Maatalouden tutkimuskeskus, Maanviljelyskemian ja -fysiikan laitos
}

Aineisto koottiin vv. 1947-69 eri puolilla Suomea sijainneiden kevätviljojen erilaisten hivenlannoituskokeiden ilman boorilannoitusta ja boorilannoituksella saaduista satotuloksista. Boorilannoitteena käytettiin kokeissa pääasiassa lannoiteboraattia ja joissakin kokeissa booraksia tai boorihappoa. Käytetty boorimäärä vaihteli $0.9-2.8 \mathrm{~kg} / \mathrm{ha} \mathrm{B}$. Lannoitteet sekoitettiin maahan kevätmuokkauksen yhteydessä.

Ilman boorilannoitusta saadun jyväsadon suuruus ei riippunut merkitsevästi maan pH:sta, kalkki-, fosfori- tai booripitoisuudesta, jotka määritettiin koetta perustettaessa otetuista maanäytteistä. Boorilannoituksella saatu satoero vaihteli varsin paljon, $-520-+580 \mathrm{~kg} / \mathrm{ha}$. Keskimääräinen sadonlisäys oli $+82 \mathrm{~kg} / \mathrm{ha}$.

Tarkasteltaessa tilastollisesti yllämainittujen maan ominaisuuksien vaikutusta boorilannoituksen tehoon ilmeni, että kevätviljojen boorilannoituksen tarpeen arviointia booriköyhillä mailla maan vesiliukoisen booriluvun perusteella näyttää olevan mahdollista parantaa ottamalla tulkinnassa huomioon lisäksi maalaji ja maan kalkkipitoisuus. 